\title{
Role of Nuclear Electricity in Low Carbon Economy
}

\author{
S. M. Sirazam Sadekin ${ }^{1}$, Sayma Zaman ${ }^{1}$, M. A. Rashid Sarkar ${ }^{2, *}$, Md. Altab Hossain ${ }^{1,2}$ \\ ${ }^{1}$ Nuclear Science \& Engineering department, Military Institute of Science and Technology, Dhaka - 1216, Bangladesh \\ ${ }^{2}$ Department of Mechanical Engineering, Bangladesh University of Engineering and Technology, Dhaka 1000, \\ Bangladesh \\ Corresponding Email: rashid@me.buet.ac.bd
}

\begin{abstract}
:
To deal with climate change, low carbon economy is an utmost necessity for the present world. Energy requirement is growing faster exponentially in each decade. Over the long term some of the traditional sources (coal, gas, oil) have become inadequate to meet up the increasing demand. Current consumption rate of fossil fuel will make them extinct by year 2050 to 2100 . Based on these facts nuclear power plant is a strategic choice to develop a clean energy. This paper presents - the role of nuclear electricity in low carbon economy. Though nuclear energy can't be called as 'carbon neutral' but it gives rise to much less emission of carbon dioxide than fossil fuels. Comparing with other energy structures, nuclear electricity chain emits a limited amount of greenhouse gas emission. Despite the uncertainty of building future nuclear power plants, this paper further discussed climate policies have larger impact than the policies that are against nuclear electricity production. The safety issue which is a public concern is also discussed here in short.
\end{abstract}

Keywords: Climate Change, Carbon Emission, Nuclear Electricity, Nuclear Reactor, Low Carbon Economy.

\section{Why Low Carbon?}

Global climate change is a burning question for the whole world and the main reason behind this is the emission of carbon dioxide. To viably diminish $\mathrm{CO}_{2}$ outflows whereas keep financial development, different nations have started to seek for modern improved ways among which lowcarbon development has ended up a broadly supported one. According to Japan's report "Building a Low-Carbon Society", a low carbon society is required to follow three principles, namely minimizing all the sectors' emission, pursuing a simple lifestyle with higher quality and getting well along with the nature [1].

Low carbon city means a city where the low carbonization of all the different aspects have been realized. Low-carbon economy cannot move forward without development in energy field [2]. For this preferred low-carbon solution, nuclear energy can be a breakthrough way which must be introduced more to the world. After hydrothermal powered electricity, Nuclear power is the second largest source of low carbon electricity. It is conceivable to generate a high amount of electrical energy in one single plant. Coal fired power plants have a wide run of undesirable chemicals into the air, counting sulfur dioxide, nitrogen oxides, mercury, particulate matter and other toxins. Besides, fossil fuels are gradually exhausting, hence it might lead to an approaching worldwide scarcity of energy.
Table 1: $\mathrm{CO}_{2}$ emission to produce $1 \mathrm{GWh}$ of electricity for various technologies [3]

\begin{tabular}{|l|l|}
\hline Technology & $\begin{array}{l}\text { Tonnes of CO} \text { emission/ } \\
\text { GWh (average range) }\end{array}$ \\
\hline Renewable sources (solar, wind) & 26 \\
\hline Nuclear power plant & 29 \\
\hline $\begin{array}{l}\text { Combined heat and natural gas } \\
\text { in private houses }\end{array}$ & 499 \\
\hline Oil burning plants & 733 \\
\hline New coal burning plants & 888 \\
\hline
\end{tabular}

Electricity Sources That Do Not Emit Carbon Dioxide During Operation

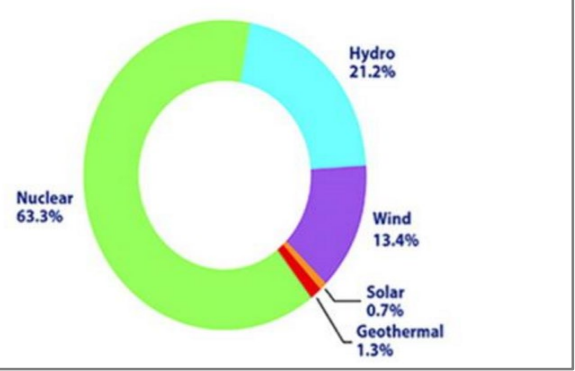

Figure 1: Electricity sources that produce low carbon power during operation in USA [4]

Nuclear power produces a huge percentage of low carbon power in the USA. Emission target would be much harder if nuclear power is removed from USA. All of these 
advantages indicate that, nuclear energy production will continue to grow and offer a low carbon, clean air to fossil fuels.

\section{World Nuclear Power Plant Status}

The world is marching forward to explore the full potential of nuclear power. This has taken the form of a revolution as countries like Russia, China, France, UK, USA has set successful examples of producing electricity by nuclear reactors. The nuclear capacity growth will be around $25 \%$ in difference of only 25 years (2015 to 2040) [5]. The first country that should be talked about when it comes to nuclear is Russia. Russia is the world leader in fast neutron reactor technology. The method that is most used in Russia is VVER (Water Water Energetic Reactor).

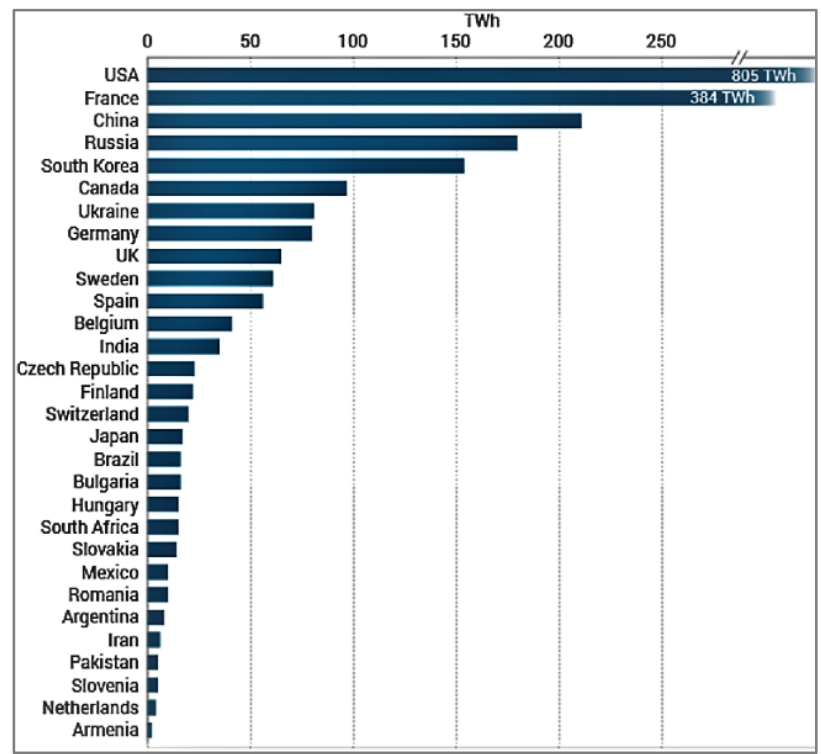

Figure 2: Nuclear generation by countries in 2013

France is a country which has set example that a country can sustain their demand by nuclear electricity. Almost $75 \%$ of their production comes from nuclear field. Though the new government has proposed to decrease the number of reactors which has raised quite an eyebrow. Another reason the world is switching to nuclear power is OECD, the Organization for Economic Co-operation and Development. It consists 34 countries and try to improve social and most importantly economic policies [6]. One of their missions is transitioning to a low carbon economy.

\section{Greenhouse Gas Emission in Nuclear Power Plants compared to Conventional Power Plants}

Greenhouse gas emission is a critical factor that needs to be considered while establishing a power plant. This factor varies drastically along with the power generating technology and source used in the power. Greenhouse gas is any vaporous compound within the air that's able of retaining infrared radiation, subsequently trapping heat within the air. By expanding the warmth within the environment, these are responsible for the impact, which leads to global warming. The longevity in the air and the amount produced from various fields makes carbon di oxide the main concern.

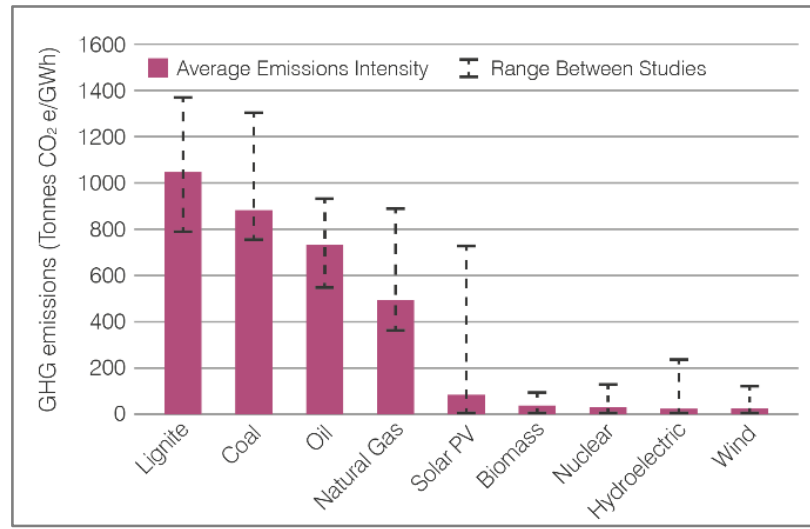

Figure 3: Greenhouse gas emission from various power plants

The World Nuclear Association did research over 20 times to prove the efficiency of nuclear plant over conventional plants. From that review it was well established that nuclear plants are far better option for low greenhouse gas emission than fossil fuel plants. So, it is clearly visible that nuclear plant is more ecofriendly than fuel-based plants along with hydro and renewable source plants. Nuclear produced electricity is the path to choose to preserve the integrity of environment and avoid global warming.

\section{Current Electricity Generation}

Electricity is a primary need in the modern world. The current development of society depends on the production of electricity. The conventional fossil fuel, reusable sources, nuclear, hydro etc. are the ways to produce electricity. Fossil fuel remains the most dominant as coal is most used as source, $38.1 \%$ in 2017.Natural gas remains second as it is used $23.2 \%$. Hydroelectricity is another source for production of electricity (15.9\%). But nuclear is still lagging behind them because their share declined by $3.4 \%$ and they have now only $10 \%$ [7]. But the OECD countries are trying to give importance to cleanly generated electricity. As a result, in OECD countries 18\% of the total electricity is coming from nuclear field [8]. Also, fossil fuels are being used to their maximum potential as a result many countries have taken initiatives 
to shift to nuclear electricity. It is not for only fulfilling the growing demand but also to ensure a safe environment.

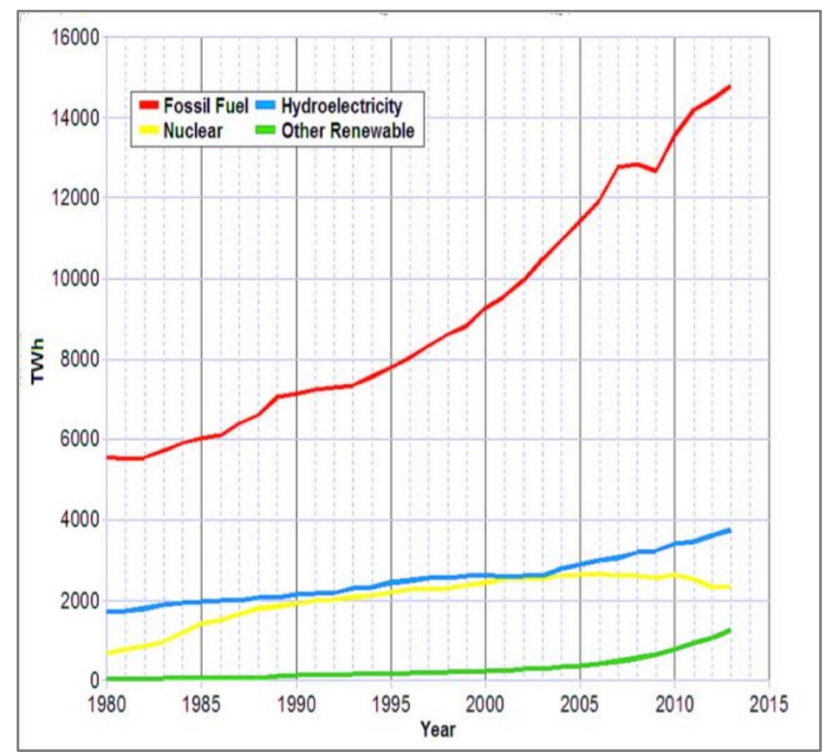

Figure 4: Electricity generation sources

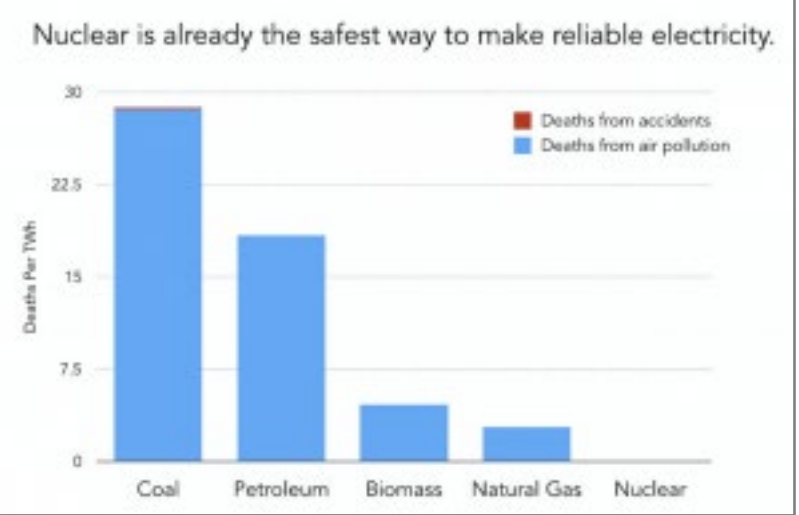

Figure 5: Accidental death from various sources

\section{Safe Technology}

'Safety' is the main concern of public regarding nuclear power plants. But nuclear power is safe compared to fossil fuels which, according to the IAEA, played a major part in the 6.5 million premature deaths attributable to air pollution in 2012 (both household and outdoor) [9]. People are afraid of nuclear energy sources because they emit radiation particles which can harm human's DNA and damage cells. But nuclear power plant doesn't emit that much radiation in the atmosphere because the reactor is shielded in a very moderate way. After the Fukushima nuclear accident in Japan in 2011, the major nuclear power countries were in a dilemma. With 440 reactors worldwide, only one (Chernobyl) has been classified as a "major accident" by the International Atomic Energy Agency (IAEA). One of the main functions of the IAEA is to act as an auditor of world nuclear safety. Each nation which works nuclear power plants contain an atomic security inspectorate and all of these works closely with the IAEA. The IAEA Security Benchmarks, created in participation with Member States, serve as a worldwide reference for ensuring individuals and the environment and contribute to a high level of security around the world.

One of the main functions of the IAEA is to act as an auditor of world nuclear safety. Each nation which works nuclear power plants contain an atomic security inspectorate and all of these works closely with the IAEA. The IAEA Security Benchmarks, created in participation with Member States, serve as a worldwide reference for ensuring individuals and the environment and contribute to a high level of security around the world.

Some safety mechanisms of Nuclear power plant are:

- Safe transportation of spent fuel

- Maintenance of core cooling

- Management of radioactive waste

- Control of radioactivity

Dealing with nuclear waste is also a concern for safety issues. All of the used nuclear fuel generated in every nuclear plant in the past 50 years would fill a football field to a depth of less than 10 yards, and $96 \%$ of this "waste" can be recycled [10]. Practically, it is impossible to make a $100 \%$ safe power plant as there will be always a probability of accident. Yet nuclear power generation process is the safest and most secure technology for producing electricity in present world.

\section{Newcomer Countries}

30 countries are considering, planning or starting nuclear power programs, and a further 20 or so countries have expressed an interest [11]. At present, 30 countries of the world are operating 449 Nuclear Power Reactors and 12 countries among them are providing $11 \%$ of the world's electricity by nuclear power. For a safe, secure and sustainable nuclear power programs, newcomer countries are following the regulations and safety guard. The emerging nuclear energy countries are now following the developed designs of the UK, USA, France, Russia, and China as these countries have the reactor design license.

- Power reactors under construction - UAE, Belarus, Bangladesh.

- Contracts signed, legal and regulatory infrastructure well-developed or developing - Turkey, Lithuania, Vietnam (but deferred). 
- Committed plans, legal and regulatory infrastructure developing - Jordan, Poland, Egypt.

\section{Innovative \& Modern Nuclear Reactors}

Innovative reactors are improved economy of scale if we compare to large reactors and smaller in size. These small reactors possessed great economic value which needs less initial cost of building a plant. Few small modular reactors are currently being proceed all over the world [12]. SMRs are usually considered to have electrical output of 300 MW or less. Several generations of nuclear reactors are distinguished. Generation i reactors were developed during 1950 - 60s. Gen ii reactors are mainly the commercial reactors. Gen iii (and iii ${ }^{+}$) are the advance reactors [13]. Also gen. iv reactors are in progress under international collaborations aiming more sustainability. Higher safety functions are additional features of it. Six systems have chosen by experts for further R \& D. They are Gas cooled fast reactor, Very high temperature reactor, Lead cooled fast reactors, Molten salt reactor, Superficial water reactor, Sodium cooled fast reactor [14].

\section{Summary}

The demand for power is increasing rapidly with the expansion of civilization. On the other hand, the environment is suffering from the conventional power plants which are emitting greenhouse gases and causing global warming. To solve all these problems, low carbon economy has become a priority to the world.

- Generally speaking, low carbon economy is the initial stage of low carbon world. Among all the low carbon options, nuclear power is one of the most beneficial one. Not only this will solve the problem of environment but also this will meet up with the increasing demand.

- Operational nuclear power plants bring remarkable environmental benefits when it comes reducing acidification, ARDPs as well eutrophication. This system maintains the natural habitats integrity.

- Nuclear power encompasses minimum level of toxicity and allows for large reductions in particulate matter formation. Radiation comes out from nuclear fuel cycle has less magnitude than natural radiation to ionizing radiation (Terrestrial/Cosmic radiation).

- If compare to counterparts, Nuclear energy production still remains less sensitive to climate change policy or geopolitical risk. The main concerns regarding nuclear power that were safety and control has been solved by developing science. Because of this increasing demand and to mitigate environmental damage nuclear power plant is being integrated into the power system.

\section{Acknowledgments}

The authors are thankful to MIST and Bangladesh Atomic Energy Commission for providing support.

\section{References}

[1] Ministry of the Environment, (2007), Building a Low Carbon Society, Government of Japan.

[2] Yuan, H., Zhou, P., \& Zhou, D., (2011), What is lowcarbon development? A conceptual analysis, Energy Procedia, 5, 1706-1712.

[3] McIntyre, J., Berg, B., Seto, H., \& Borchardt, S., (2011), Comparison of lifecycle greenhouse gas emissions of various electricity generation sources, World Nuclear Association (WNA) Report.

[4] Conti, J. J., Holtberg, P. D., Beamon, J. A., Schaal, A. M., Ayoub, J. C., \& Turnure, J. T., (2014), Annual energy outlook 2014, US Energy Information Administration, 1269.

[5] Cobb, J., \& Nowacki, T. R., (2017), World nuclear performance report, VGB PowerTech, 12, 77-82.

[6] Organisation for Economic Co-operation and Development, About the OECD, Accessed online at https://www.oecdwatch.org/oecd-guidelines/oecd

[7] British Petroleum, (2018), BP statistical review of world energy $2018,67^{\text {th }}$ edition.

[8] World Nuclear Association, (2014) World Energy Needs and Nuclear Power, Accessed online at http://www.worldnuclear.org/information-library/current-and-futuregeneration/world-energy-needs-and-nuclear-power.aspx

[9] International Energy Agency, (2016), Energy and Air Pollution: World Energy Outlook Special Report.

[10] Krane, K. S., (1988), Introductory Nuclear Physics, John Wiley and Sons.

[11] World Nuclear Association, (2011), Emerging Nuclear Energy Countries: WNA Report.

[12] Corradini, M. L., (2007), New reactor technology: safety improvements in nuclear power systems, Health physics, 93(5), 547-559.

[13] World Nuclear Association, Advanced nuclear power reactors, Accessed online at http://www.worldnuclear.org/info/inf08.html.

[14] Kim T.K., (2012), GEN-IV Reactors, In: Meyers R.A. (eds) Encyclopedia of Sustainability Science and Technology, Springer, New York, NY. 